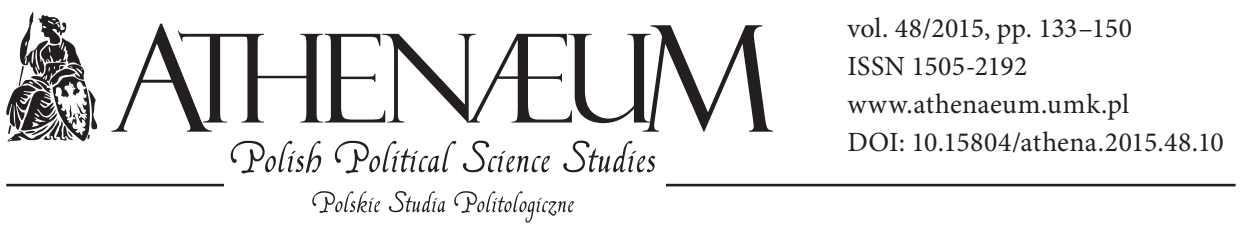

\title{
RUSSIA'S ENERGY COOPERATION WITH CHINA IN THE NEW ERA
}

\author{
Mo Guo*
}

\begin{abstract}
Last year (2014), after years of negotiation, China signed a gas supply contract with Russia, which is a milestone of Sino-Russian energy cooperation. This contract gives us a chance to review the development of Sino-Russian energy cooperation and relations in the past 15 years. By analysing this long history, we found that today's achievement is the result of diverse determinants.

It is necessary to understand these elements and consider energy cooperation against the background of economic development, international relations and world governance, so that we can understand how the energy deal was made and what it means to both countries in different aspects.

For both countries, today's progress is the consequence of internal needs and external pressures. Russia seeks for new market and tries to avoid political and economic risks. China needs strategic reserve and a proper political partner. More importantly, both sides hold the consensus that the energy cooperation could bring effect on political level.

They set an example of how big powers cooperate and how they solve disputes. The high level of political and strategic consensus has played an essential role in this cooperation. This politically-oriented characteristic contributes to today's breakthrough, however, on the other hand, it could also bring unstable and fragile factors.
\end{abstract}

\section{KEYWORDS -}

Sino-Russian relations, energy cooperation, Russia’s Energy Policy

* University College London, England. 


\section{THE NEW CONTRACT IN 2014}

In May 2014, the president of the Russian Federation Vladimir Putin visited Shanghai to attend a key summit of Asian states that included delegates from nearly 40 countries and international organizations.

It was Putin's first visit to China since President Xi Jinping took office. Against the backdrop of the sanctions of western countries caused by the crisis in Ukraine and the closer relations of Russia and China in the recent years, expectations were high that this visit could make big progress in the practical cooperation of many fields. Although the officials remained silent, it was already an open secret that Putin's visit was "with a gas supply deal on the agenda" (BBC 2014a).

However, things were not as easy as people expected. On the night of May $20^{\text {th }}$, the press revealed that there would not be an expected gas contract signing during Putin's visit, due to the price difference (Zhang 2014). On that day, Russia and China signed more than 40 cooperation documents without the gas deal. It was such a disappointing night for both countries - regardless of all the clues and hints that had suggested a big breakthrough, nothing really happened, again, like always.

Then the surprise came in the morning. Russia and China signed the longawaited gas supply agreement on the last day of Putin's visit. This last-minute deal is expected to deliver some 38 billion cubic meters of natural gas a year eastward to China's burgeoning economy, starting around 2018 (BBC 2014b). According to the media, "the two countries will invest more than $\$ 70$ billion on the world's largest construction project, with Russia providing $\$ 55$ billion up front and China $\$ 22$ billion for pipelines on their respective territories” (RT, 2014). “This is the biggest contract in the history of the gas sector of the former USSR", said Putin, after the agreement was signed between state-controlled entities Gazprom and China National Petroleum Corp (CNPC) (Reuters 2014a). Moreover, the gas contract marks the new era of energy trading of two countries: there was no natural gas (except LGN) trading before between the strategic partnerships.

The dramatic and volatile story shows the difficulty and complexity behind the negotiations. Putin described the Chinese as difficult and hard negotiators, noting that "talks went on until 4 a.m." (Reuters 2014b). "Both sides were in the end pleased by the compromise reached on price and other terms", the president's words are the only details we knew about that night. Not surprisingly, no official price was given by both countries but it is estimated to be worth over $\$ 400 \mathrm{bn}$. Sources say that the price is around $\$ 350-\$ 380$ per thousand cubic meters, which 
would benefit both China and Russia, as it is cheaper than Asian spot market LNG prices and slightly above Russia's break even costs (Reuters 2014).

The secret price and unveiled details of the negotiation raised doubt and discussions in the press and among the people. Although there were different voices about the price and policy making, the mainstream in China still expressed a positive attitude towards this epochal contract. From Russia's side, people seem satisfied with their new big client and their choice to tie up with China, particularly in the face of the tense situation with the West.

It is obvious that this gas supply agreement is not simply the result of business and trade struggle. Actually, any kind of energy cooperation is not only about business, especially between China and Russia, but rather it contains many issues, such as international security, political strategy, regional politics, and global governance. It is the many connections between these two countries that have led to today's achievement. Therefore, to better understand how the energy deal was agreed and what it means to both sides, one has to keep the foresaid elements in mind and put the energy policy into the context of international relations and politics.

We cannot deny that the gas contract reflects the close relations between Russia and China, and so do the doubts, questions and secret interactions behind the contract, from which we can learn more about the partnership between these two powers.

According to recent official documents and representations, relations between Russia and the People's Republic of China "are developing successfully and have reached a new level of comprehensive partnership and strategic cooperation" (Kremlin 2014) This sets the tone of bilateral relations and the basic direction of future development; however, the consequences behind the headline are far more complicated.

\section{HARD AND TORTUOUS DEVELOPMENT: FROM 2001 ONWARDS}

Russian-Chinese relations are always the focus of the world. As two main powers in the current multi-polar world, Russia and China have become closer and closer since their strategic partnership was founded.

China and Russia are in its best years at the moment. Before Vladimir Putin's visit to Shanghai in 2014, in October of 2013, Prime Minister of the Russian 
Federation Dmitri Medvedev visited China for the $18^{\text {th }}$ routine meeting between prime ministers since 1996, and signed many agreements with China. Just as Putin said to the press earlier that year when China's new leader Xi Jinping chose Russia for his first visit abroad, the Russian-Chinese relations "are the best in their centuries-long history" (ITAR-TASS 2014).

Looking back, diplomatic relations between Russia and China rapidly improved after the dissolution of the USSR and the founding of the Russian Federation in 1991 when Russia and China signed a Joint Statement on the foundation of relations, in which the two countries pledged to "establish goodneighbourly, friendly and mutually beneficial relations" when the then Russian President Boris Yeltsin made his first official visit to China. In 1994, their bilateral relationship was defined as a "constructive partnership", and the description of the relations in 1996 turned into an "equal and reliable, strategic partnership of coordination towards the $21^{\text {st }}$ century".

A special moment of Russian-Chinese relations was marked on July $16^{\text {th }}$, 2001, when the then Chinese President Jiang Zemin and Russian President Vladimir Putin signed "The Treaty of Good-Neighbourliness, Friendship and Co-operation between Russia and China", a programmatic treaty to confirm the strategic partnership of coordination, aiming at "establishing a foundation for the long-term comprehensive development of relations and strategic interaction between the two countries within an equal and trust-based partnership" (Portyakov 2010: 2-4). In the same year they joined with Kazakhstan, Kyrgyzstan, Tajikistan, and Uzbekistan in the Shanghai Cooperation Organization (SCO).

The complementary agreement between China and Russia on the Eastern Section of the China-Russia Boundary signed in 2004 ended the territorial disputes that had lasted hundred years, and were seen as the last issue of conflict between Russia and China.

Today, Russia and China have a "comprehensive strategic cooperative partnership", the highest level they have ever reached since 2001. Interaction and communication at the top level between the two countries has become more frequent. Having the same position on many issues, like anti-terrorism, antiseparatism, and ethnic issues, the two permanent members of the UN Security Council have consensus on most of the intense global issues which have a huge impact on the world. In the latest Ukraine crisis, although China kept their word at the beginning in terms of concern about their relations with Ukraine and hot topic domestic issues, Beijing allied with Russia by claiming that they oppose sanctions with Russia over Ukraine (Reuters 2014b). 
Besides, both countries deepened their co-operation through the contexts of G20, BRICS, and the SCO, and this enhanced their influence on global governance and at the geopolitical level.

From the economic aspect, Russia and China have seen a dramatic increase in the total trade value in the past decade. According to statistics from the National Bureau of Statistics of The People's Republic of China, the total value of trade between Russia and China jumped to $89.2^{\text {bn }}$ dollars in 2013 up from $10.6^{\text {bn }}$ dollars in 2001 (National Data 2014). The first Russia-China crude pipeline, built in 2010, started to work in 2011, representing the development of energy trade during these years.

China has become the biggest trade partner with Russia today, and according to the plan of two countries (before the gas deal of 2014), the bilateral trade value will reach 100 billion dollars per year in 2015, and 200 billion by 2020 (Chinanews 2013).

However, in comparison with the very frequent political interaction and high consensus at global governance level, the trading component is somewhat different. It is noted that today's 90 billion dollars in trade value between Russia and China, the so-called big achievement of rapid development, accounts only $20 \%$ of the total trade value between China and America. We could say that political consideration in this scenario is more important than really practical economic development for both countries - at least the facts give this impression. There are countless frame agreements and memorandums as well as joint declarations between Moscow and Beijing that have been signed since 2001, but many of them are just concepts and political declarations, or propaganda, which are not that pragmatic and efficient especially in terms of the economy.

The idea of oil supply from Russia to China was first proposed in 1996, when Yeltsin signed "the energy cooperation agreements between China and Russia" during his visit to China (People.cn 2014). In 2001, Yukos first proposed an Oil Pipeline project, which would help transfer Yokos's oil to Daqing, a northern Chinese city. However, the project stalled in 2003 because of the arrest of Mikhail Khodorkovsky. Then in 2006, after the agreement providing Transneft with 400 million dollars for constructing a pipeline from Skovorodino to China signed by CNPC, the pipeline started to be built. It was not until 2011 that the first Russia-China crude pipeline came into full use.

The situation is even worse in terms of gas trading. The starting point for gas cooperation was the agreement in 1996, which proposed the idea of transporting gas from the Irkutsk to China. Then the long and tortuous negotiations started. 
During the past 17 years, the two countries have signed a series of framework agreements, and have established an energy negotiation mechanism at the vice premier level, but still without a conclusive end. Many reasons have caused these marathon negotiations, but price is generally acknowledged to be the biggest obstacle. Briefly, the two "close partners" did not want to compromise in the negotiations. It is clear that they both long for a final deal, which matches the status quo of their intimate relations at the political and strategic level, nevertheless the procedure lasted 17 years.

In the opinion of Shoichi Itoh, a large part of the Sino-Russian energy partnership is rhetorical rather than substantial (Itoh 2010). Thanks to the 2014 gas supply contract, we should re-evaluate energy connections between China and Russia in the new era of Sino-Russian relations.

Since 2001, China's imports of crude oil from Russia are getting better. In 2001, China imported 1.8 million tons of oil from Russia, and received 5.3 million tons in 2003. The first time oil trading reached 10 million tons was in 2004, and this climbed to 16 million tons in 2006, which was the record during the 2000s. As a result of the crude oil pipeline being put into use between China and Russia in 2011, oil imports reached the 20 million tons level. In 2013, China imported 24.35 million tons of oil from Russia, which made Russia the $4^{\text {th }}$ largest oil trading partner of China (China Energy News 2014). Although imports from Russia account for $7.8 \%$ of the total oil imports of China, these are at present far behind those of Saudi Arabia, Angola, and Iran (Guangzhou Daily 2014).

In order to expand trade, China created a new mode: Loans-for-Oil. In 2009, China and Russia signed a series of commercial contracts including a big deal for Loans-for-Oil. According to the contract, China Development Bank and CNPC offered a 20-year-loan to the state company Rosneft and Russian pipeline monopoly Transneft, of approximately 15 billion dollars and 10 billion dollars respectively. In response, indebted Rosneft would supply 15 million tons of oil to China each year, and Transneft had to finish the first phase of the construction of the Sino-Russian pipeline by 2009 (Pipeline and Gas Journal 2009). The Loans-for-Oil strategy met the demands for both sides: Russia received funds while China secured oil supply. This method is still working today not only in terms of Sino-Russian oil cooperation, but also in deals with other partners.

As the disputes being gradually resolved, it seems that the energy cooperation between China and Russia was changing into a highway from the previous bumpy rough roads. In 2013, Russia signed with China a $\$ 270$ billion deal to double the oil supply to China (Reuters 2013). According to the contract, Rosneft 
will export 360 million tons of crude oil to China in the following 25 years (Qian 2013: $72-73$ ). Also in 2013, CNPC bought a 20\% stake in OAO Novatek's $\$ 20$ billion Yamal liquefied natural gas project, aiding the Russian gas supplier's bid to raise financing (Bloomberg 2013).

To conclude, the situation of energy cooperation between the two partners is improved in the past five years. Contract has been signed, oil is being transported, and the gas is on the road - the tough days have passed. All of these are closely related to Russia's energy policy and the world situation.

\section{A GENERAL TREND?}

Energy trade is a complex business which is inseparable with a nation's strategy and policy. Examining Russia's energy policy towards China is a direct approach to understanding energy relations between Russia and China. Nevertheless, there is no single Russian energy policy in practice despite the notable Russia's energy strategy until 2030 (ES2030), a key document for Russia's energy sector (Aalto 2012: 5). Published in 2009, the directional document is an updated version of Russia's energy strategy until 2020. The ES2030 reviews the previous document and considers its effect, sets new strategies, and predicts the future of energy needs, energy production, and economic development. ES2030 describes Russia's energy strategy in terms of turning to the east: "By 2030, the proportion of Eastern energy markets in the Russian energy export of liquid hydrocarbons (oil and oil products) should grow from the current 6 to $22-25 \%$, while natural gas exports should grow from 0 to $19-20 \%$ " (ES2030 2009). In contrast, the proportion of exports to the West will decrease in order to remove dependence on the Western market.

Without a doubt, China as a key player of Eastern energy market is involved in ES2030. In the "going east" strategy, natural gas is a significant component for its implementation since Russia owns the largest natural gas reserves in the world while its development eastward just begins.

Shinichiro Tabata and Xu Liu explained three objectives of Russian oil and gas development in the Far East and East Siberia: exploitation of oil and gas fields to replace those in West Siberia, diversification of Russia's oil and gas exports, and economic growth in the Far East and East Siberia (Tabata, Liu 2012: 156-180). West Siberia, notably the Tyumen oblast, has been at the heart of Russia's energy production since the mid-1970s (Tabata, Liu 2012: 156-180). That area produces 
$60 \%$ of Russia's oil and about $90 \%$ natural gas, according to statistics in 2012 (EIA 2013). As the needs of the Western market have stagnated in recent years, coupled with China's rising consumption in the East, production in the West Siberian fields is projected to decline. In the future, untapped oil reserves in Eastern Siberia and the Russian Arctic may play a larger role. Eastern Siberian oil and gas area cover an area of approximately 3.3 million square kilometres. Russia has started exploring these untapped resources. Though it is not clear about the accuracy of these estimates, the Eastern Siberian area is definitely a secret weapon for Russia: “the region's potential was increased with the inauguration of the Eastern Siberia-Pacific Ocean (ESPO) pipeline, which created an outlet for East Siberian oil" (EIA 2013). In the Far East area, the prospects are more stunning. Sakhalin Island, the biggest island of Russia with complicated history and territorial disputes, is the home of a number of large oil and gas fields. "Only in Sakhalin were foreign companies allowed to join the exploration and exploitation of oil and gas resources in Russia" (Tabata, Liu 2012: 156-180) - this special policy is designed by government to encourage development in the Far East.

It is not a secret that exports of oil and gas are of crucial importance to the growth of the Russian economy and its finance (Gaddy, Ickes 2010). Russia's economy is highly dependent on its hydrocarbons, and oil and gas revenues account for more than half of the whole budget revenues. According to the EIA report, "oil and gas revenues accounted for $52 \%$ of federal budget revenues and over 70\% of total exports in 2012" (EIA 2013).

As energy exports are so important to Russia, they are trying to protect and solidify their trade and transportation to secure a healthy and stable cash cow. Unfortunately, the price of energy is floating (or falling), and the tendencies for supply and demand are not in Russia's control. Energy security has become a troublesome case for Russia. There are too many determinants that influence energy trading between Russia and Europe. Avoiding risk is a reasonable choice in this situation. Therefore, Russia has the strong will to diversify its oil and gas exports. The East and the Asia-Pacific area geographically are natural alternatives for Russia.

Productivity and reserves are also essential conditions, while the needs of the market are the reason for Russia's eastward shift. Except for the security dimension, market needs play a crucial role.

The global market has changed a lot in recent years: "Russia's oil and gas exports in the future are stagnating demand in the European market" (Tabata, Liu 2012). The rising proportion of China's demand is another change. In 2012, 
China became the second largest oil consumption country in the world while its partner Russia took second place for oil production (BP 2013). Moreover, China is also the second-largest net importer of oil in the world, while China also became a net gas importer in 2007 (BP 2013).

By 2013, more than 55\% of oil consumption of China relies on imports, and $24 \%$ of gas comes from other countries (BP 2013). The International Energy Agency (IEA) predicts that China's dependence on imported oil will increase to $80 \%$ by 2030 (Downs 2010: 146-175). This emphasizes the huge potential of China's market.

There are so many instabilities in the trading between Russia and Europe. In particular, the current situation between Europe and Russia might make things even worse. With the insecure European market and an enlarging Chinese market, Russia's decision to switch to the east seems reasonable and feasible.

However, we should note that European countries still dominate and will dominate Russia's energy trade, its huge demand still is and must be Russia's priority target at that moment. To exploit the market in the Asian Pacific does not mean that Russia will abandon the European market. It is a daunting task for Russia to adjust their structure and strategy while grasping both the west and the east market at one time.

Realizing the importance of energy and the geopolitical position in East Siberia and the Far East, the Russian government has started to focus on these areas. So, the tilt to East Siberia and Far East meets Russia's internal needs for regional development.

China invests more in Siberia today. Officially, the Outline of the Regional Cooperation between Northeast China and the Russian Far East Area and Eastern Siberia has started its implementation. With its strong economic power, China's influence in the Siberian area is increasing. The local economy of the Far East has become increasingly reliant on Chinese goods, services, and labour. In this situation, bilateral cooperation in the energy field is undoubtedly logical.

This brings us to the question of China's role. What can China offer and what Russia will gain through this cooperation? A simple answer is, money for energy. However, there are more elements behind the contract. Russia's energy is seen as a safe and convenient supply to China, but it is not that necessary at that moment, because China has already cultivated a series of energy suppliers, including natural gas, LNG, crude oil, and even coal. In this context, Russia's energy is more like a strategic preparation for China. From the perspectives of energy security and long term strategy, Russia's energy could help China 
to diversify their supplier and reduce the cost of imports, since geographically Russia is the nearest supplier to China. Moreover, China's unremitting endeavour to enter the upstream of Russia's energy industry has caused fear for Russia. For China, only by entering into Russia's upstream can she ensure that the oil and gas from their partner are reliable and stable. So, deepening the cooperation with Russia could bring more opportunities for the following cooperation upstream.

In today's situation, Russia has lost its advantages and initiative. The pressure of the West has forced Russia to seek a new market and make a fast strategic shift. The oil price keeps falling. Most importantly, Russia's economy is in recession. Ranking No.8 in GDP globally (World Bank 2014), Russia is gradually losing its edge, especially in comparison with China. Today's China has become the biggest trade partner for Russia, while Russia only ranks No.9 amongst all of China's trade partners (National Data 2014). Clearly, Russia needs more in the relations. The balance between Russia and China has changed. Just as James Bellacqua suggested, Russia is increasingly becoming the "junior partner" in the relationship (2010: 1-12).

This brings us to look at those negative elements that restrict the development of cooperation and influence the energy export policymaking of Russia, especially in the energy sphere.

First of all, China has many other partners in the energy sphere. As mentioned before, today China imports oil mostly from Saudi Arabia, Angola, and Iran; imports natural gas from Central Asia through a pipeline; and imports LNG from Qatar, Australia, and Malaysia. Russia is not in a dominant position.

Secondly, these two strategic partners have some dubious and ambiguous approaches to competition in the Central Asia area. Both countries intend to bring Central Asia into their energy plan, and that is exactly what they are doing now. Russia still see Central Asia as its sphere of influence, but "Beijing is also interested in new markets for China's good and in Central Asia's energy supplies"(Trenin 2012).

Finally, the "China Threat" is being talked about in Russia. There is awareness of the increasing inequality between these two powers and Russia's weakening position as compared to China (Kaczmarski 2013: 5). In the energy sphere, China tries to go into Russia's upstream while Russia has been reluctant to admit Chinese investment in upstream gas market. Someone describes this as an "equity stakes dilemma" (Skalamera 2014: 12-17). The mistrust of two countries is like a landmine in the process of cooperation and policymaking. 
Luckily, the Kremlin seems to hold an optimistic view and see China as an opportunity more than a threat. Putin has recognized that "China's growth is not a threat and Russia needs to catch the Chinese wind in the sails of our economy" (Putin 2012). Since the economic crisis, Russia started to think about deeper and pragmatic cooperation with China. That is why negotiations and cooperation sped up in recent five years after slow development since 2001.

To sum up, it is a general trend for Russia to seek further cooperation with China from the aspect of strategy. Moreover, it is a compulsory choice as well: Russia needs China, and Russia has to make deals with China as they have no other alternatives.

\section{CHINA'S VIEW}

The new gas supply agreement has triggered a huge wave of discussion in China's press and internet. People have been talking about the secret price, the history of the negotiations, and the ups and downs of Sino-Russian relations. Except trying to solve puzzle of price, another focus has been the debate of the pros and cons of this deal. Did China win or lose?

The question is obviously caused by the secret price, as this was seen as the major difficulty among those long negotiations. Many experts and journalists have offered their own guesses about the price to evaluate the profits and loss associated with the final contract. And interestingly, they have drawn totally different conclusions. Some think that the final price is a success for Russia (Rusnews.cn 2014); while other think that the price is closer to China's lowest expectations (Xiaocui 2014). The majority believe that the final price is higher than the price Central Asia offers to China, while lower than the price that the European market gets from Russia. We should know that the price could be defined in many ways, and it is a complex formula with many variables. Actually, it is meaningless to limit the discussion to the circle of calculation, the more important factor is to evaluate it at the level of strategy, and detect the information behind the numbers.

Another concern is the timing of this contract. Liang Fang, a researcher in China, has questioned China's policymaking in this cooperation in consideration of the current bad political and economic circumstances for Russia. He analysed Russia's situation after the Ukraine Crisis and the sanctions of the West, and pointed that it may not be a good timing for China to sign this contract. If China 
had dragged on the talks longer, they could have totally dominated the situation and made a better offer (Liang 2014). This kind of voice represents a sort of concern about this gas contract.

At the superficial level, China has the emerging needs for energy; they also focus on energy security and future reserves. Moreover, in consideration of serious air pollution in recent years, China desires to acquire cleaner energies like natural gas. How could the negotiation last more than 10 years if two sides were both hungry? Why this brings many questions to China and why the tiny gain and loss were discussed? The bilateral mistrust created obstacles for the pragmatic cooperation.

From Itoh's view, diplomacy and negotiations between Moscow and Beijing have been difficult, owing largely to Russian concerns about fuelling China's economic growth to its own geopolitical detriment: "although cooperation with China in the energy field has a huge potential, Russia has yet to make the most of this opportunity due to its own deep-rooted geopolitical mind-set" (Itoh 2010).

From China's side, the concerns and mistrust mainly come from Russia's xenophobia and their attitude towards the world political arena. In the global arena, China hesitates when coping with Russia's aggressive acts. In Ziegler's opinion, China is a rising power, but "its foreign policy has been oriented toward preserving the status quo, fostering the conditions for strong economic growth and social stability domestically" (2010: 83-145). Trenin thinks that the mutual support in global issues and regional problems has its limits (Trenin 2012).

Therefore, it is reasonable for China to keep cautious when they deal with Russia.

\section{POLITICALLY-ORIENTED ENERGY COOPERATION: RUSSIA, CHINA, AND THE WORLD}

There are various indications that today's energy cooperation between China and Russia has a kind of strong politically-oriented characteristic. Both Russia's energy export policymaking and China's view have strong strategic and political indications behind the scene. Interestingly, it is the political concerns that caused the low efficiency in the past, and it is the political needs that make the deal happen today.

It is widely believed that the Ukraine crisis has pushed Russian energy towards China (Katakey 2014). But as previously described, the whole story is 
not so straightforward. As close comrades, China has no possibility of opposing Russia directly, while in consideration of the very frequent military and agricultural cooperation with Ukraine, China has kept its word and avoided expressing a clear view and has abstained from voting in the UN. Surprisingly, China's ambiguous attitude has been interpreted as a kind of support. Putin thanked China because Chinese leaders "have always considered the situation in Ukraine and Crimea taking into account the full historical and political context" (Putin 2014). This is how China became involved in the Ukraine Crisis and became Russia's supporter, though not undertaken directly.

Paradoxically, when Putin came to Shanghai in 2014, China changed its previous "neutral" attitude. In the joint statement, some messages pointed to the Ukraine Crisis and Russia's rivals: "The sides noted the need to respect historical heritage of countries, their cultural traditions and independently chosen public and political system, the system of values and ways of development; counteract interference in domestic affairs of other countries, give up the language of unilateral sanctions, organize aid, fund or encourage activity aimed at changing a constitutional system of a foreign country or its involvement in any multipartite association or union" (Joint Statement 2014). Needless to say, China's clear attitude satisfied Russia, who is now increasingly isolated by the West.

Weighed and balanced, China has tried to obtain some support from Russia in terms of territorial issues and regional tension as well as possible concessions in energy negotiations by giving a hand to Russia. It is hard to say whether it works or not, but at least, in 2014, when Russia was in crisis and had to find partners to face the West, and when China was forced to face pressure because of Diaoyu Islands and with Philippines, the unsmooth energy talks hitched the ride of strategic allying.

Given the truth that energy trade between Russia and China is politicallyoriented, we should consider the role of China and Russia together in terms of global governance.

The world has changed into a new multi-polar order since the Cold War ended. Russia's influence on the global stage has been undermined since the end of Cold War and the collapse of the Soviet Union. Serious domestic problems and emergencies like power struggles, the Chechen War, and the economic crisis have erupted. In spite of this, Russia has still tried to preserve its impacts and never underestimated its rights and opportunities to be a powerful force in the world. From the religious perspective, Russia's strong Messianism makes it more 
active and responsible. On the other hand, the glorious USSR and its imperial history has given them a sort of self-pride and narcissism.

This idea is also present in the foreign policy of Russia: "Rapid acceleration of global processes and growing trends in global development need a new vision of priorities in Russia's foreign policy, taking into account Russia's increased responsibility for setting the international agenda and shaping the system of international relations" (Foreign Policy Concept of Russia 2000: 1-14).

With the economic globalization and multi-polar nature of the world structure, Russia needs to find a new way to remain engaged in international relations. Joint and in cooperation with China, Russia seems not alone in the complicated and fast changing international situation. Or clearly, as many have argued, the balance that Russia wants to keep is in terms of the relations between China, Russia, and the USA.

If Russia and China maintained sound bilateral relations, it could build a positive counterweight among the big powers in the world. More importantly, it is not a conflict or competition but a new mode of development in the new order, which is constantly stressed by the leaders of two countries.

China, unlike Russia, sticks to its peaceful development policy without interfering much with international issues. With the continuous changes of the world situation and rising national strength, China has realized that "global governance and global security includes issues such as the stability of the financial markets, terrorism, the environment, food safety and non-proliferation, which is essential to China's further development" (Jisi 2011: 68). In the energy sphere, the stable supply, the safe transportation, and the increased number of cleaner resources are relevant to regional peace and global situation. This pushes China to be more active in multilateral institutions (Jisi 2011).

Clearly, some common interests in the energy sphere and common concerns in security do make these two countries closer and in greater need of each other. Moscow and Beijing understand that they can make a contribution to world stability and maintain a balance with the USA, or the West. They need to gain their space and their common sphere of influence in the fast changing world. Just as Putin talked about Russia's cooperation with China on the global stage: "The commonality of our approaches to fundamental issues of world order and key international problems has become an important stabilizing factor in world politics" (ITAR-TASS 2014).

Everything between Russia and China is under the background of political consensus, which is an example of how major nations get along in geopolitical 
issues. So is the energy connection. If there were no geopolitical consensus, and no sense of global governance, today's gas deal as well as the comprehensive Sino-Russian energy partnership would never exist.

Without a doubt, politically-oriented energy trade works today. It relies on the current global political situation, on the Russia's needs and China's role, also on the tradition and history of bilateral relations. Although there has been mistrust and problems between the two countries, that kind of mistrust would never cross the bottom line of the "unprecedentedly high level of partnership" (Xinhua News 2013). But it could hurt if we focus too much on political level.

There is a long way to go for both countries to gain real, equal, and mutually beneficial energy cooperation. China should avoid taking the partnership back to the "comprehensive unconditionally friendly", as China had been with the USSR. After all, the previous ideological alliance between China and Russia did not bring good outcomes. For Russia, when dealing with Sino-Russian energy trade, they should not see it as a "Chinese Card" to threaten the West or establish closer diplomatic relations with Beijing. Moscow should know that what Russia really needs are stable trade relations, which are sustainable and beneficial.

\section{CONCLUSION}

Referring back to the 2014 gas supply contract, after years of negotiation, Russia and China finally reached an agreement on gas pipeline construction and natural gas supply. This is the biggest energy contract so far between Russia and China, and could reset the pattern of energy trade in the world. As big powers in the world that have shared a similar history and have been very close in the past, Russia and China's breakthrough in terms of energy cooperation has farreaching impacts, and is worthy of research in the field of energy policy, as well as international relations.

This long awaited gas supply agreement symbolizes that Russia's energy cooperation with China has entered a new era: a cooperation based on a high degree of political consensus and common interests, aiming at a pragmatic mutual beneficial outcome. Today's progress is the consequence of internal needs and external pressures.

From the perspective of Russia, it needs to seek other markets to avoid the potential risks of the European market, and grow their economy especially in the less-developed area in the east. China, in contrast, is a country with a huge 
demand for clean and stable energy supply, which could help Russia to diversify its export structure, and more importantly, give it support to exploit and develop Eastern Siberia and the Far East. Strategically, the energy cooperation between Russia and China might be a strong resultant force to ensure energy security and to balance the powers at the regional level as well as global arena. The economic needs are the roots; the partnership is the guarantee, while the changes to the global political situation are the driving forces.

They set an example of how big powers cooperate and how they solve disputes. Moreover, at the same time, they have specific features where high levels of political and strategic consensus have played an essential role in this cooperation. This politically-oriented feature has stimulated today's big achievement, and will direct following deeper development. Nevertheless, the political connection could restrict energy cooperation as well. We need to note that the partnership still includes unstable and fragile factors: mistrust and competition to some extent influence the energy trade. Therefore, there is a long way to go for these two big countries to maintain a rapid pace to implement and to push forward their burgeoning energy cooperation.

\section{REFERENCES:}

Aalto P. (ed.). (2012). Russia's Energy Policies: National, Interregional and Global Levels. Cheltenham: Edward Elgar Publishing.

BBC. (2014a). Russia's Putin Seeks Gas Deal on State visit to China. May 20. [online] http://www.bbc.co.uk/news/world-asia-china-27481454; [accessed 01.02.2015].

BBC. (2014b). Russia Signs 30-year Gas Deal with China. May 21. [online] http://www. bbc.co.uk/news/business-27503017; [accessed 01.02.2015].

Bellacqua J. (2010). Contemporary Sino-Russian Relations Thirteen Years of a Strategic Partnership. [in:] The Future of China-Russia Relations. J. Bellacqua (ed.). Kentucky: University Press of Kentucky.

Bloomberg. (2013). CNPC Buys Stake in Novatek's Yamal LNG Project in Russian Arctic, September 5. [online] http://www.bloomberg.com/news/2013-09-05/ cnpc-buys-stake-in-novatek-s-yamal-lng-project-in-russian-arctic.html; [accessed 10.09.2014].

BP GROUP. (2013). Statistical Review of World Energy 2013, June 2013. [online] http:// www.bp.com/content/dam/bp/pdf/statistical-review/statistical_review_of_world_ energy_2013.pdf; [accessed 01.02.2015].

China and Russia Sign 20-year Oil Deal. (2009). "Pipeline and Gas Journal”Vol. 236, No. 6. [online] http://www.pipelineandgasjournal.com/china-and-russia-sign-20-yearoil-deal; [accessed 10.09.2014]. 
China Energy News. (2014). February 2. [online] http://news.xinhuanet.com/ energy/2014-02/02/c_126081716.htm; [accessed 01.02.2015].

Chinanews. (2013). Ministry of Commerce: Xi Jinping's Visit Will Promote Trade and Investment Cooperation Between China and Russia, March 19. [online] http://www. chinanews.com/gn/2013/03-19/4656167.shtml; [accessed 10.09.2014].

Downs D. (2010). Sino-Russian Energy Relations, an Uncertain Courtship. [in:] The Future of China-Russia Relations. J. Bellacqua (ed.). Kentucky: University Press of Kentucky, Kentucky.

Energy Strategy of Russia for the Period up to 2030, November 13, 2010. [online] http://www.energystrategy.ru/projects/docs/ES-2030_(Eng).pdf; [accessed 10.09.2014].

Gaddy C., Ickes B. (2010). Russia after the Global Financial Crisis. "Eurasian Geography and Economics" 51, No. 3.

Guangzhou Daily. (2014). Countries China Imports Oil From, April 6. [online] http:// news.163.com/14/0426/07/9QO7B0R800014AED.html; [accessed 01.02.2015].

ITAR-TASS. (2014). RF-Chinese Relations Best in Centuries-Long History - Putin. March 22. [online] http://en.itar-tass.com/russia/691211; [accessed 01.02.2015].

Itoh S. (2010). Sino-Russian Energy Relations: True Friendship or Phony Partnership. "Russian Analytical Digest" 73 (10).

Jisi W. (2011). China's Search for a Grand Strategy - A Rising Great Power Finds its Way. "Foreign Affairs" 90.

Kaczmarski M. (2013). The Bear Watches the Dragon: the Russian Debate on China. "Point of View" 31. Warsaw: Centre for Eastern Studies (OSW).

Katakey R. (2014). Crimea Crisis Pushes Russian Energy to China From Europe. [online] http://www.bloomberg.com/news/2014-03-25/russian-oil-seen-heading-east-notwest-in-crimea-spat.html; [accessed 10.01.2015].

Liang F. (2014). Zhongguo Dui E Weihe Ruci Houdao?. [online] http://dajia.qq.com/ blog/395661128784551; [accessed 10.09.2014].

National Bureau of Statistics of the People's Republic of China. (2014). [online] http:// data.stats.gov.cn/workspace/index? $\mathrm{m}=$ hgnd; [accessed 20.03.2014].

People.cn. (2014). Events Chronicle of Sino-Russian Energy Cooperation. May 22. [online] http://energy.people.com.cn/n/2014/0522/c71661-25049224.html; [accessed 10.09.2014].

Portyakov V. (2010). Russian-Chinese Relations: Current Trends and Future Prospects. "Russian Analytical Digest" 73.

Press Statement Following Russian-Chinese Talks. (2014). [online] http://eng.kremlin. ru/transcripts/7200; [accessed 19.12.2014].

Putin V. (2012). Russia and the Changing World. "Moscow News". [online] http://rt.com/ politics/official-word/putin-russia-changing-world-263/; [accessed 10.09.2014].

Putin V. (2014). Address by President of the Russian Federation. [online] http://eng. kremlin.ru/news/6889; [accessed 10.01.2015].

Qian L. (2013). Zhong E Shiyou Maoyi De Beihou. "Neng Yuan" 7. 
Reuters. (2013). Rosneft to Double Oil Flows to China in $\$ 270$ Billion Deal. June 21. [online] http://uk.reuters.com/article/2013/06/21/us-rosneft-china-idUSBRE95K08820130621; [accessed 10.09.2014].

Reuters. (2014a). As Putin Looks East, China and Russia Sign \$400-billion Gas Deal. May 21. [online] http://www.reuters.com/article/2014/05/21/us-china-russia-gasidUSBREA4K07K20140521; [accessed 19.12.2014].

Reuters. (2014b). FACTBOX-Details of Russia-China Gas Deal. May 22. [online] http://uk.reuters.com/article/2014/05/22/gas-russia-china-pipeline-idUKL6N0O81TU20140522; [accessed 19.12.2014].

RT. (2014). Russia and China Seal Historic \$400 ${ }^{\text {bn }}$ Gas Deal. May 21 [online] http:// rt.com/business/160068-china-russia-gas-deal/; [accessed 01.02.2015].

Rusnews.cn. (2014). Zhuanjia: Duihua Gongqi Hetong Shi Eluosi De Chenggong. [online] http://sputniknews.cn/russia_china_relations/20140522/44070812.html; [accessed 10.09.2014].

Skalamera M. (2014). Booming Synergies in Sino-Russian Natural Gas Partnership. Harvard Kennedy School.

Tabata S., Liu X. (2013). Russia's Energy Policy in the Far East and East Siberia. [in:] Russia's Energy Policies: National, Interregional and Global Levels. P. Aalto (ed.). Cheltenham: Edward Elgar Publishing.

Trenin D. (2012). True Partners? How Russia and China See Each Other. Centre for European Reform.

Xiaocui L. (2014). Zhong E Qiaoding Tianranqi Dadan Daodi Shi Kuile Haishi Zhuanle?. [online] http://wallstreetcn.com/node/91200; [accessed 10.09.2014].

Xinhua News. (2013). China-Russia Relations at Unprecedented High Level: Medvedev. October 22. [online] http://news.xinhuanet.com/english/china/201310/22/c_132820701.html [accessed 10.01.2015].

Zhang Zh. (2014). 21 Century Business Herald. [online] http://epaper.21cbh.com/ html/2014-05/20/content_99116.htm?div=-1; [accessed 19.12.2014].

Ziegler C.E. (2010). Russia and China in Central Asia. [in:] The Future of China-Russia Relations. J. Bellacqua (ed.). Kentucky: University Press of Kentucky. 